\title{
Cristianismo numa sociedade plural: a propósito do livro de Boaventura de Sousa Santos "Se Deus fosse um ativista dos direitos humanos"
}

\author{
Christianity in a pluralistic society: considerations from the book "If God \\ Were a Human Rights Activist", by Boaventura de Sousa Santos.
}

\section{Resumo}

\begin{abstract}
Esta Comunicação aborda a problemática do cristianismo numa sociedade plural a partir do livro de Boaventura de Sousa Santos Se Deus fosse um ativista dos direitos humanos, onde se confronta com os desafios que os "movimentos que reivindicam a presença da religião na esfera pública" apresentam aos direitos humanos no contexto de uma "ecologia de concepções da dignidade humana". Começa apresentando a problemática do cristianismo numa sociedade plural e indicando duas formas fundamentais de diálogo e interação entre as tradições religiosas e o conjunto da sociedade. Prossegue mostrando, a partir do livro acima referido, como tradições e movimentos religiosos são (ou podem ser) um lugar privilegiado de afirmação e defesa da dignidade humana e como as teologias que os sustentam constituem uma "gramática de defesa da dignidade humana". E conclui mostrando como a afirmação e defesa da dignidade humana, compreendidas e vividas no contexto das lutas sociais por justiça, constituem o núcleo da experiência cristã de Deus ou, em todo caso, uma de suas características ou marcas fundamentais.
\end{abstract}

Palavras-chave: Direitos humanos; Religião; Dignidade Humana; Lutas sociais.

\begin{abstract}
This paper discusses the issue of Christianity in a pluralistic society on the basis of the book "If God Were a Human Rights Activist", by Boaventura de Sousa Santos. In this book the author confronts the challenges that the "movements that demand the presence of religion in the public sphere" place for human rights in the context of "ecology of conceptions of human dignity." This article begins by presenting the problem of Christianity in a pluralistic society and indicating two fundamental forms of dialogue and interaction between religious traditions and society as a whole. The text goes on to show, from the aforementioned book, how traditions and religious movements are (or can be) a privileged place of affirmation and defense of human dignity and how theologies that sustain them constitute a 'defense grammar of human dignity. The article concludes by showing how the affirmation and defense of human dignity, understood and lived in the context of social struggles for justice, constitute the core of the Christian experience of God or, in any case, one of its fundamental features or marks.
\end{abstract}

Keywords: Human rights; Religion; Human dignity; Social struggles.

Comunicação recebida em 06 de julho de 2015 e aprovada em 20 de dezembro de 2015.

* Doutor em Teologia na Westfälischen Wilhelms-Universität de Münster - Alemanha; Presbítero da Diocese de Limoeiro do Norte - CE

e Professor de Teologia no Instituto Teológico Pastoral do Ceará. País de origem: Brasil. E-mail: axejun@yahoo.com.br 


\section{Introdução}

O tema desta reflexão é amplo e complexo. Pode ser desenvolvido em perspectivas e pontos de vista diversos ou até mesmo contrastantes e exige um tratamento que extrapola nossas pretensões e condições, bem como os limites de espaço como esse. A explicitação destes limites logo no início do texto não se deve a nenhuma falsa modéstia nem quer ser um mecanismo sutil de autodefesa e blindagem contra possíveis e razoáveis críticas que possam ser feitas à nossa abordagem. Devem-se, antes, a uma questão de honestidade intelectual que diz respeito tanto à consciência dos limites da abordagem que faremos, quanto da necessidade de sua ampliação, complementação ou mesmo correção.

Começaremos esboçando a problemática do cristianismo numa sociedade plural (I); desenvolveremos o tema nos termos da relação entre religião e dignidade humana, tal como aparece no livro de Boaventura de Sousa Santos, indicado no subtítulo deste artigo (II); concluiremos mostrando que a problemática da afirmação e defesa da dignidade humana constitui o núcleo da experiência cristã de Deus (III).

\section{A problemática do cristianismo numa sociedade plural}

Tornou-se comum nas últimas décadas falar de "crise de civilização", "crise epocal”, “crise de paradigma" ou "mudança de época" como característica fundamental de nosso tempo. Embora os enfoques e as análises e descrições dessa crise e/ou mudança sejam diversos, coincidem na constatação de que vivemos um momento novo na história da humanidade ou, em todo caso, na história do Ocidente.

Dentre as características que comumente se atribuem a esse momento novo da nossa história, ganha destaque o caráter plural de nossas sociedades. Vivemos 
em sociedades profundamente diversas e plurais: plurais do ponto de vista dos interesses econômicos, políticos, culturais, ambientais, de gênero, étnico-raciais; plurais do ponto de vista do comportamento e da ação morais; plurais do ponto de vista dos valores e dos critérios que orientam e regulam a ação das pessoas e a organização da sociedade; plurais do ponto de vista da orientação sexual e da configuração familiar; plurais do ponto de vista religioso etc.

Neste contexto, é inevitável a pergunta pela importância, pelo lugar e pela missão que as tradições religiosas - concretamente o cristianismo - têm ou podem ter em uma sociedade plural. Pergunta necessária e urgente, tanto para as tradições religiosas (em vista de sua afirmação e de seu desenvolvimento em uma sociedade plural), quanto para o conjunto da sociedade (dado o crescimento da presença e intervenção de grupos religiosos na vida pública).

Essa pergunta pode ser respondida de muitas formas. Em tempos passados, chegou-se a decretar a "morte de deus" e o "fim da religião". A explosão de movimentos religiosos nas últimas décadas, no mundo inteiro, reivindicando inclusive participação ativa na vida pública, por mais complexa e ambígua que seja; entretanto, parece contestar estes decretos ou estas teses e abrir espaço para uma interação e um diálogo crítico-criativos das tradições religiosas com o conjunto da sociedade.

Grosso modo, podemos identificar, entre nós, duas formas fundamentais de compreensão e efetivação positivas dessa interação e desse diálogo: uma de caráter mais teórico-linguístico (diá-logo), que tem em Jürgen Habermas uma de suas principais referências; outra de caráter mais práxico (inter-ação), desenvolvida pelas teologias da libertação e, mais recentemente, pelo sociólogo Boaventura de Sousa Santos (SANTOS, 2014).

No primeiro caso, reconhece-se a importância e a contribuição das tradições 
religiosas, particularmente no contexto de uma "sociedade pós-secular". Antes de tudo, no que diz respeito ao "aspecto motivacional" (HABERMAS; RATZINGER, 2007, 33-39, 51). Mas também no que diz respeito ao seu "conteúdo" (HABERMAS; RATZINGER, 2007, 49s), desde que ele seja traduzido numa linguagem ou num "discurso secular". Partindo de uma "diferenciação" (HABERMAS; RATZINGER, 2007, 47) e mesmo de uma suposta "assimetria das pretensões epistêmicas" (HABERMAS; RATZINGER, 2007, 49) entre o "discurso religioso" e o "discurso secular", impõe-se, aqui, o desafio de uma tradução ou "transposição" (HABERMAS; RATZINGER, 2007, 50) secular dos conteúdos religiosos ou de uma "apropriação de conteúdos genuinamente cristãos pela filosofia” (HABERMAS; RATZINGER, 2007, 49), tal como se deu, por exemplo, com "a transformação da condição de similaridade com Deus do ser humano em dignidade igual e incondicional de todos os seres humanos" (HABERMAS; RATZINGER, 2007, 50). Não obstante o valor e a contribuição dessa posição, haveria que discutir - aqui - tanto a pretensa superioridade epistêmica e universalidade do "discurso secular" (elitismo!?), quanto a pretensa radicalidade da linguagem ou do discurso na vida humana (idealismo!?) (GONZÁLEZ, 1994, 638$639 ; 2008,40-44)$.

No segundo caso, a importância e a contribuição de tradições e movimentos religiosos dizem respeito à sua intervenção concreta em favor da dignidade humana. Em geral, eles têm um potencial ético-espiritual profundamente humanizador, não obstante todos os riscos de fundamentalismo e intolerância e de instrumentalização ideológica. Diferentemente da postura anterior, o desafio fundamental - aqui - não é de ordem teórico-linguístico (tradução ou transposição), mas de ordem práxica (intervenção ou interação).

\footnotetext{
${ }^{1}$ A expressão "pós-secular" diz respeito tanto ao "reconhecimento público pela contribuição funcional que [as comunidades religiosas] prestam à reprodução de motivos e atitudes", quanto à "conviç̧ão normativa" de que a "modernização da consciência pública" afeta "tanto as mentalidades religiosas quanto as seculares, modificando-as de forma reflexiva". De modo que "ambos os lados estarão em condições de levar a sério em público, por razões cognitivas, as respectivas contribuições para temas controversos" (HABERMAS RATZINGER, 2007, 52). “A neutralidade ideológica do poder do Estado que garante as mesmas liberdades éticas a todos os cidadãos é incompatível com a generalização política de uma visão de mundo secularizada” (HABERMAS - RATZINGER, 2007, 57).
} 
No que se refere à questão específica da linguagem ou do discurso, tampouco se afirma aqui uma superioridade epistêmica do “discurso secular” sobre o "discurso religioso", nem vice-versa. Pelo contrário. Reconhecendo as "limitações" dos muitos discursos ou linguagens, Boaventura de Sousa Santos abre espaço e aponta para uma “ecologia de saberes”, isto é, "um exercício epistemológico baseado na incompletude de qualquer tipo de conhecimento humano e destinado a identificar conhecimentos distintos e critérios de rigor e validade que operam credivelmente nas práticas sociais de modo a desenvolver interações criativas entre eles” (SANTOS, 2014, 107).

Nas trilhas abertas e desenvolvidas pelas muitas teologias da libertação vinculadas a muitos processos de libertação; mais recentemente, formuladas e propostas por Boaventura de Sousa Santos que nos confrontaremos com a problemática do cristianismo numa sociedade plural. Num primeiro momento, mostrando como tradições e movimentos religiosos são (ou podem ser) um lugar privilegiado de afirmação e defesa da dignidade humana e como as teologias, mais ou menos explicitas e elaboradas, que os sustentam, constituem uma "gramática de defesa da dignidade humana” (SANTOS, 2014, 29). Num segundo momento, mostrando como a afirmação e a defesa da dignidade humana constituem o núcleo da experiência cristã de Deus.

\section{Religião e dignidade humana}

Conforme indicado acima, tomaremos como referência, neste trabalho, o livro de Boaventura de Sousa Santos Se Deus fosse um ativista dos direitos humanos $^{2}$. Mas não vamos fazer uma apresentação global e crítica da obra. Isso é tarefa para recensão (NOGOSEKE, 2014, 1097-1104; TOLDY, 2014). Consideraremos apenas sua tese fundamental que, por razões didáticas, pode ser formulada em quatro pontos coerentemente articulados: A) "a ideologia da

\footnotetext{
${ }^{2}$ A partir de agora, os números entre parênteses, sem outra indicação, remetem a páginas desta obra.
} 
autonomia e do individualismo possessivos é hoje contrariada por duas políticas normativas principais que [...] procuram operar globalmente: os direitos humanos e as teologias políticas" (11); B) os movimentos religiosos/teológicos pluralistas e progressistas "podem ser uma fonte de energia radical para as lutas contrahegemônicas dos direitos humanos" (12); C) esses movimentos "constituem uma gramática de defesa da dignidade humana que rivaliza com a que subjaz aos direitos humanos e muitas vezes a contradiz" (29); D) essa rivalidade ou contradição abre "a possibilidade de novas relações e diálogos entre [concepções alternativas de dignidade humana]", mediante uma "ecologia de saberes" que tem como objetivo "ampliar a legitimidade intelectual e cultural das lutas pela dignidade humana" (107). Sua pretensão última, como explicita no prefácio da obra, é "realizar um exercício de tradução intercultural entre estas duas políticas normativas, procurando zonas de contato para tradução entre elas donde possam emergir energias novas ou renovadas para a transformação social radical progressista" (12).

Estas reflexões nasceram da observação e constatação no Fórum Social Mundial que vem se realizando desde 2001 de "como os ativistas da luta por justiça socioeconômica, histórica, sexual, racial, cultural e pós-colonial baseiam frequentemente o seu ativismo e as suas reivindicações em crenças religiosas ou espiritualidades cristãs, islâmicas, judaicas, hindus, budistas e indígenas” (12). Estas "subjetividades políticas", diz ele, "combinam efervescência criativa e energia apaixonada e intensa com referências transcendentes ou espirituais que, longe de as afastarem das lutas materiais e bem terrenas por um outro mundo possível, mais profundamente as comprometem com estas" (13). Daí seu propósito ao escrever este livro: "dar conta destas subjetividades e destas lutas para as fortalecer e, afinal, também para dar sentido às minhas vivências com umas e outras" (13).

Para isso, A) começa identificando "a fragilidade dos direitos humanos enquanto gramática da dignidade humana e os desafios que a emergência das teologias políticas lhes coloca no início do século 21"; B) distingue “diferentes tipos 
de teologias políticas" e de "discursos e práticas contrastantes de direitos humanos" e seleciona "os tipos de reflexão e prática que podem contribuir para expandir e aprofundar o cânone das políticas de direitos humanos"; C) conclui defendendo que "as teologias pluralistas e progressistas podem ser uma fonte de energia radical para as lutas contra-hegemônicas dos direitos humanos" (12, 145). Noutras palavras, parte da hegemonia e fragilidade dos direitos humanos, enquanto gramática da dignidade humana, confronta-se com a globalização e a complexidade das teologias políticas; e aponta para uma “concepção pós-secularista dos direitos humanos” ou para uma “ecologia de concepções da dignidade humana”.

\section{A) Hegemonia e fragilidade dos direitos humanos}

Boaventura de Sousa Santos começa sua reflexão com uma afirmação desconcertante que aparece já no título da introdução da obra - "Direitos humanos: uma hegemonia fraca" (15): “A hegemonia dos direitos humanos como linguagem de dignidade humana é hoje incontestável. No entanto, [...] a grande maioria da população mundial não é sujeito de direitos humanos. É objeto de discursos de direitos humanos" (15). Essa situação leva-nos a questionar "se os direitos humanos servem eficazmente à luta dos excluídos, dos explorados e discriminados ou se, pelo contrário, a torna mais difícil” (15); e, em todo caso, "mesmo sendo parte da mesma hegemonia que consolida e legitima sua opressão", se eles poderão "ser usados de modo contra-hegemônico" (16). O enfrentamento dessas questões acaba levantando outras tantas que, em conjunto, revelam a complexidade da problemática e o modo como autor lida com ela: "Por que há tanto sofrimento injusto que não é considerado uma violação dos direitos humanos? Que outras linguagens da dignidade humana existem no mundo? Se existem, são ou não compatíveis com a linguagem dos direitos humanos?” (16).

"A busca de uma concepção contra-hegemônica dos direitos humanos deve começar por uma hermenêutica da suspeita em relação aos direitos humanos tal como são convencionalmente entendidos e defendidos, isto é, em relação às 
concepções dos direitos humanos mais diretamente vinculadas à matriz liberal e ocidental destes" (16). Neste sentido, é preciso começar reconhecendo que "os direitos e o direito têm uma genealogia dupla na modernidade ocidental” (16). Por um lado, uma "genealogia abissal" que dividiu o mundo entre "sociedades metropolitanas e colônias" e em que "os direitos humanos foram historicamente concebidos para vigorar apenas [...] nas sociedades metropolitanas” (17). Por outro, uma "genealogia revolucionária", ligada ao "individualismo burguês" e à "sociedade burguesa" emergente que se consolida com as revoluções americana e francesa e que articula direito-liberalismo-capitalismo (17) - base da "hegemonia" e do “consenso" de que gozam os direitos humanos em nossas sociedades (17s).

"Hegemonia" e "consenso" assentam-se em "ilusões" que "constituem o senso comum dos direitos humanos convencionais" (18). O autor distingue e apresenta quatro destas ilusões. Em primeiro lugar, a "ilusão teleológica" que “consiste em ler a história da frente pra trás”, absolutizando o presente e tratando “ações de opressão e dominação" como “ações emancipatórias de libertadoras” (18). Em segundo, a "ilusão triunfalista", segundo a qual "a vitória dos direitos humanos é um bem humano incondicional" e "todas as outras gramáticas da dignidade humana [...] eram inerentemente inferiores em termos éticos e políticos", sem considerar o fato decisivo da complementação da "força das ideias" com a "força bruta das armas" (19). Em terceiro, a ilusão da "descontextualização" que silencia ou ofusca o fato de que, desde suas origens até os nossos dias, “os direitos humanos foram usados, como discurso e como arma política, em contextos muito distintos e com objetivos contraditórios” - revoluções burguesas, invasões, discursos e práticas contra-revolvucionárias (20s). Em quarto e último lugar, a ilusão monolitista que "consiste em negar ou minimizar as tensões e até mesmo as contradições internas das teorias dos direitos humanos" (22): “direitos do homem e do cidadão" (22), “direitos individuais e coletivos” (23).

“Ter presente estas ilusões é crucial para construir uma concepção e uma prática contra-hegemônica de direitos humanos, sobretudo quando elas devem 
assentar num diálogo com outras concepções de dignidade humana e outras práticas em sua defesa" (26). Parte-se, então, da constatação de que "a compreensão do mundo excede - em muito - a compreensão ocidental do mundo e, portanto, a compreensão ocidental da universalidade dos direitos humanos" (28). E isso se pode comprovar em vários "movimentos de resistência contra a opressão, marginalização e exclusão que têm vindo a emergir nas últimas décadas e cujas bases ideológicas pouco ou nada têm a ver com as referências culturais e políticas ocidentais dominantes ao longo século XX”, como é o caso dos "movimentos indígenas" na América Latina, dos "movimentos de camponeses na África e na Ásia” e da "insurgência islâmica”, dentre outros (28s). Estes movimentos estão "enraizados em identidades históricas multisseculares, incluindo muitas vezes a militância religiosa"; eles "comungam do fato de provirem de referências políticas não ocidentais e de se constituírem como resistência ao domínio ocidental" (29).

Neste livro, Boaventura de Sousa Santos se concentra "nos desafios aos direitos humanos quando confrontados com os movimentos que reivindicam a presença da religião na esfera pública". Estes movimentos "constituem uma gramática de defesa da dignidade humana que rivaliza com a que subjaz aos direitos humanos e muitas vezes a contradiz" (29).

\section{B) Globalização e complexidade das teologias políticas}

Junto à constatação da hegemonia e fragilidade dos direitos humanos, como gramática da dignidade humana, está a constatação da presença global e complexa de movimentos religiosos com suas teologias políticas na vida pública: "A reivindicação da religião como elemento constitutivo da vida pública é um fenômeno que tem ganhado relevância nas últimas décadas em todo o mundo”, constituindo-se, inclusive, como "fenômeno global” (31). Trata-se de um fenômeno extremamente complexo e num duplo sentido. Da parte dos movimentos religiosos, ele se constitui como "um fenômeno multifacetado, tanto no que respeita às denominações envolvidas como no tocante às orientações políticas e culturais” (31). 
No que diz respeito ao seu caráter global, é preciso reconhecer que “a globalização não é um fenômeno monolítico e que as relações transacionais são uma teia de duas globalizações opostas que por vezes seguem paralelas e por vezes se interceptam" (31): "globalização hegemônica neoliberal” X "globalização contrahegemônica ou globalização a partir de baixo” (32-36) (SANTOS, 2001, 25-102), distinção extremamente importante na consideração do processo de "globalização das teologias políticas” (31).

Para Boaventura de Sousa Santos, embora se trate de "um fenômeno que tem vindo a assumir uma importância crescente nas últimas décadas”, como no caso dos "processos de globalização" em curso, "não estamos perante um fenômeno novo” (36). Basta recordar o papel desempenhado pelo catolicismo e pelo islã nos processos de conquista e colonização no ocidente e no oriente. "É novo apenas na medida em que ocorre depois de séculos de dominação colonial e neocolonial, e de imposição global do paradigma cultural e político da modernidade ocidental” (36).

No que diz respeito à questão do "papel da religião na sociedade” (36), este paradigma está estruturado a partir da "distinção entre o espaço público e o espaço privado" e do "confinamento da religião" no espaço privado (37). Isso é o que se apresenta "hoje" como "um elemento central do imaginário político ocidental, tanto no plano da regulação social como no da emancipação social”, dá-se de modo bem concreto "com os direitos naturais do século XVII e com seus sucessores: constitucionalismo moderno e Declaração de Direitos Humanos das Nações Unidas” (37).

É precisamente essa "resolução ocidental da questão religiosa" que vem sendo posta em questão por parte de movimentos religiosos com suas teologias políticas que reivindicam "o papel da religião na vida pública" (36). Por "teologias políticas", o autor entende "os diferentes modos de conceber a intervenção da religião, como mensagem divina, na organização social e política da sociedade” (38); “de modo mais ou menos radical, todas as teologias políticas questionam a 
distinção moderna entre o público e o privado e reivindicam a intervenção da religião na esfera pública” (39).

Dito isso, é necessário chamar atenção para a diversidade de teologias políticas, com as diferenças, tensões e mesmo oposições que as caracterizam e que se dá no interior das mais diversas tradições religiosas; particularmente, nas tradições monoteístas (39s). Neste contexto, o autor faz uma dupla "classificação" das teologias políticas, não obstante os limites e os ricos de toda classificação.

A) "Quanto ao âmbito da intervenção da religião na esfera pública, devemos fazer uma distinção entre teologias pluralistas e fundamentalistas" (40). Enquanto para as teologias fundamentalistas "a revelação é concebida como o princípio estruturante da sociedade em todas as suas dimensões" e "está normalmente ligada ao escriturismo", as teologias pluralistas "concebem a revelação como um contributo para a vida pública e à organização política da sociedade, mas aceitam a autonomia de ambas", buscando um "equilíbrio" entre razão e revelação. Distinguem-se, pois, tanto na "relação entre razão e revelação", quanto na "relação entre revelação e história" (42).

B) "No tocante ao critério ou à orientação da intervenção religiosa, podemos distinguir entre teologias tradicionalistas e progressistas" (47). Enquanto as tradicionalistas "intervêm na sociedade política defendendo como melhor solução para o presente, as regulações sociais e políticas do passado”, subordinando “a autoridade política à autoridade religiosa" (47) e recusando “a distinção entre a religião dos oprimidos e a religião dos opressores" (48), as teologias progressistas "fundam-se na distinção entre a religião dos oprimidos e a religião dos opressores e criticam severamente a religião institucional como sendo a religião dos opressores” (48).

"A distinção entre diferentes tipos de teologia [...] permite ver que as relações entre os fenômenos religiosos emergentes, as formas de globalização e os direitos humanos não são unívocas ou monolíticas". Embora, "no tocante à globalização, todas as teologias políticas são não hegemônicas, uma vez que são 
marginais"; apenas "as teologias pluralistas progressistas contém um forte potencial contra-hegemônico" (53): “Ao reconhecer a relativa autonomia do espaço secular e ao fazer um julgamento crítico das injustiças que nele ocorrem, a religião dos oprimidos pode ser uma fonte de articulação entre os movimentos religiosos e seculares que lutam por uma sociedade mais justa e mais digna” (53s).

Em todo caso, “A emergência das teologias políticas gera novas zonas de contato entre concepções rivais de ordem social e transformação social com as novas formas de turbulência política, cultural e ideológica daí derivantes” (91), lançando "uma nova luz sobre os limites da política dos direitos humanos a uma escala global” (82). Essas "turbulências" (princípios rivais, raízes X opções, religioso $\mathrm{X}$ secular) normalmente "refletem diferentes dimensões da injustiça global constitutiva da ordem imperial na sua fase mais recente: injustiça socioeconômica, injustiça cognitiva (incluindo a injustiça epistêmica, sexual, racial e religiosa) e a injustiça histórica” (104).

Interessa-nos destacar apenas a "turbulência" entre "o religioso e o secular" (98-102) como expressão de "injustiça religiosa" (104), indicando "a fraqueza da resposta dos direitos humanos neste domínio” e, sobretudo, apontando para uma concepção e prática contra-hegemônica dos direitos humanos (107).

\section{C) "Para uma concepção pós-secularista dos direitos humanos"}

A emergência de teologias políticas pluralistas progressistas no cenário global com sua reivindicação de intervenção na organização social e política da sociedade abre espaço e aponta para uma concepção e prática "contrahegemômicas" e "pós-secularistas” de direitos humanos. Isso acontece tanto por seu potencial contra-hegemônico humanizador e libertador quanto por seu potencial crítico-profético frente à concepção hegemônica de direitos humanos.

Quando fala de “direitos humanos contra-hegemônicos”, Boaventura de 
Sousa Santos se refere às "lutas contra o sofrimento humano injusto, concebido no sentido mais amplo e abrangendo a natureza como parte integrante da humanidade" (111). Ora, as teologias pluralistas progressistas estão vinculadas a "práticas religiosas baseadas na comunidade, para as quais Deus se revela no sofrimento humano injusto, nas experiências de vida de todas as vítimas de dominação, opressão ou discriminação e nas lutas de resistência que elas promovem". A tal ponto que "prestar testemunho a este Deus significa denunciar este sofrimento e lutar contra ele". Aqui, precisamente, "reside a possibilidade de ligar o retorno de Deus a um humanismo trans-moderno concreto”. Para ele, “um diálogo entre os direitos humanos e as teologias progressistas é não só possível como é provavelmente um bom caminho para desenvolver práticas verdadeiramente inter-culturais e mais eficazmente emancipadoras”. Esse diálogo proporcionará um "auto-enriquecimento mútuo", aprofundando o "potencial emancipador de ambos". E terá como resultado "uma ecologia de concepções da dignidade humana, algumas seculares, outras religiosas”, produto de uma "hermenêutica diatópica”, isto é, “um exercício de interpretação transformadora, orientada para a prática social e política, entre os topoi dos direitos humanos e os topoi das teologias políticas progressistas" (113).

Em seguida, passa a indicar algumas das contribuições que as teologias pluralistas progressistas, particularmente as teologias da libertação, oferecem para uma ampliação da compreensão e prática dos direitos humanos, no contexto de uma "ecologia de concepções de dignidade humana":

a) "Podem ajudar a recuperar a 'humanidade' dos direitos humanos", afirmando o "sujeito humano simultaneamente enquanto indivíduo concreto e ser coletivo" (113) frente a teorias, conservadoras ou progressistas, que levam a "desacreditar a resistência individual e coletiva contra a injustiça e a opressão" (114);

b) Estão atentas e ligadas às "múltiplas dimensões do sofrimento humano injusto" (115); por isso, "diferem de acordo com o povo, grupo social ou tipo de sofrimento específico que privilegiam”: desigualdade social, discriminação sexual 
contra as mulheres, racismo (indígenas, chicanos, negros), discriminação étnica e religiosa (judeus, palestinos, cristãos coreanos, dalits indianos) etc. (116-124);

c) "Acesso denso, direto e intenso à carne em sofrimento" (125) sem despolitizá-lo (126), ou seja, articulação “entre a ligação visceral de um gesto assistencial, de um cuidado incondicional, e a luta política contra as causas do sofrimento como parte da tarefa inacabada da divindade” (127);

d) "Uma vontade radical insurgente e um horizonte pós-capitalista" (127), "razão pela qual as mobilizações religiosas que no nosso tempo reclamam a esfera pública são sustentadas por uma espécie de radicalismo que não encontramos na maioria dos movimentos sociais" (128) vivido na luta "contra o poder, a injustiça e a opressão, quer ocorra na esfera pública ou privada, e independentemente das suas causas, incluindo as religiosas" (128);

e) "Impulso para a interculturalidade nas lutas pela dignidade humana" (129), como testemunham os diálogos ecumênicos e inter-religiosos (130) e, sobretudo, os processos históricos tenso-criativos em que as religiões ocuparam "as zonas de contato entre diferentes culturas e formas de saber, fronteiras, encruzilhadas [...]”, antecipando “o estádio intermédio, o estar-entre epistemológico sem o qual os intercâmbios interculturais não poderiam ser bem sucedidos" (132);

f) "Pela sua insistência na narrativa concreta do sofrimento das vítimas e da sua luta contra os opressores, as teologias políticas progressistas podem contribuir para tornar o sofrimento injusto numa presença intolerável que desumaniza tanto as vítimas quanto os opressores, quanto ainda aqueles que, não se sentindo nem vítimas nem opressores, veem no sofrimento injusto um problema que não lhes diz respeito" (135s);

g) Para além da contribuição nos processos de "interpretação, produção e partilha de significados" (136), são particularmente sensíveis à "presença" que 
"precede" e extrapola o "significado" (136). "A presentificação do passado ou do outro por meio de ritos, rituais e sacramentos [...] desempenha um papel central na experiência religiosa" (138), gerando um "sentido intensificado de partilha e presença que, se for colocado ao serviço das lutas de resistência e libertação da opressão, pode contribuir para fortalecer e radicalizar a vontade de transformação social" (139), como se pode verificar naquilo que no MST se costuma chamar "mística" (138);

h) "Possibilidade de libertar uma nova energia na sociedade, injetando nas lutas sociais a força motivadora contida na espiritualidade” capaz de fazer muitos ativistas de direitos humanos pagarem "com as suas vidas o empenho que puseram nas lutas pela justiça social”, como comprovam o martírio de Martin Luther King, de Oscar Romero e de "tantos crentes anônimos cujos sacrifícios nunca chegam às notícias" (142).

Em síntese, não obstante seus limites e seus riscos, as teologias pluralistas progressistas podem, a partir de sua experiência espiritual, alargar enormemente o horizonte de compreensão e prática da dignidade humana. Isso se dá de muitas formas: afirmando o "sujeito humano" individual-coletivo, estando atentas às "múltiplas dimensões do sofrimento humano injusto", mantendo uma "ligação visceral” com o sofrimento sem despolitizá-lo, radicalizando a luta contra toda forma de injustiça e opressão, impulsionando a "interculturalidade nas lutas pela dignidade humana”, narrando o sofrimento das vítimas e sua luta por libertação, insistindo no primado e na força da "presença" sobre a "interpretação" e cultivando “a espiritualidade das/nas lutas materiais pela transformação social”.

O autor conclui a obra reafirmando que "as teologias pluralistas e progressistas podem funcionar como uma fonte de energia radical para as lutas contra-hegemônicas dos direitos humanos" (145) e explicitando o sentido metafórico do título do livro: "Na lógica deste livro, se Deus fosse um ativista dos direitos humanos, Ele ou Ela estariam definitivamente em busca de uma concepção contra-hegemônica dos direitos humanos e de uma prática coerente com ela. Ao fazê-lo, mais tarde ou mais cedo, este Deus confrontaria o Deus invocado pelos 
opressores e não encontraria nenhuma afinidade com Este ou Esta. Por outras palavras, Ele ou Ela chegariam à conclusão de que o Deus dos subalternos não pode deixar de ser um Deus subalterno" (148)3.

No contexto específico de nossa reflexão acerca do cristianismo numa sociedade plural, Boaventura de Sousa Santos aponta para o potencial humanizador e libertador das religiões, pelo menos na forma como tem sido vivida e pensada pelos movimentos e teologias da libertação. Nesta perspectiva, a cristianismo deve ser vivido e pensado de modo "contra-hegemônico" ou "a partir de baixo" (32), em interação e diálogo com os mais diversos movimentos de libertação, alargando e aprofundando a compreensão e a prática da dignidade humana. Tudo isso no contexto do que ele denomina "uma ecologia de concepções de dignidade humana" (113).

\section{Dignidade humana e cristianismo}

No item anterior, vimos com Boaventura de Sousa Santos como as religiões em geral podem e muitas vezes se constituem como "uma fonte de energia radical para as lutas contra-hegemônicas dos direitos humanos” (144). Esta não é uma afirmação gratuita e abstrata nem muito menos ingênua. É uma afirmação que nasce da observação e do contato com militantes e movimentos religiosos comprometidos com as mais diversas lutas por justiça no mundo (cf. 12s). O autor sabe que estes militantes e movimentos representam uma parcela minoritária e muitas vezes perseguida no interior de suas próprias tradições ou organizações religiosas; mas capta muito bem seu potencial "contra-hegemônico" na sociedade e

\footnotetext{
${ }^{3} \mathrm{O}$ autor tira, aqui, uma conclusão bastante discutível não só do ponto de vista religioso e histórico, mas também do ponto de vista lógico: "Um Deus monoteísta apelando ao politeísmo como condição para que a invocação de Deus nas lutas sociais e políticas por uma transformação social progressista não tenha efeitos perversos. A ideia de um Deus subalterno será a de que apenas o politeísmo permite uma resposta inequívoca a esta questão crucial: de que lado estás?" (148). A própria abordagem que o autor faz das teologias pluralistas progressivas, particularmente as teologias da libertação, demonstra a problematicidade e inconsistência dessa afirmação. Sem falar que o monoteísmo cristão é, se se pode falar assim, um monoteísmo pluralista (!?) tanto na forma de nomear Deus (Pai, Filho, Espírito Santo), quanto na forma de se relacionar com Ele (processos históricos de libertação).
} 
sua contribuição para a ampliação da compreensão e prática da dignidade humana, no contexto de uma “ecologia de concepções da dignidade humana” (113).

As religiões são consideradas, portanto, a partir e em vista da afirmação da dignidade humana, isto é, das "lutas contra o sofrimento humano injusto" (111). Daí o "critério de base" usado pelo autor na consideração de pessoas e práticas religiosas: "De que lado estão? Do lado dos opressores ou do lado dos oprimidos? Do lado do fundamentalismo ou do lado do pluralismo? Do lado do tradicionalismo reacionário ou do lado da transformação social progressista?” (146).

Alguém poderia reagir contra essa abordagem, acusando-a de reducionista e instrumentalizadora. Como se as religiões e as práticas religiosas fossem reduzidas à sua dimensão ou ao seu potencial ético e fossem instrumentalizadas ou manipuladas em vista de certos interesses sociais. Um tipo de abordagem que comprometeria a integralidade das tradições e práticas religiosas ou, pior ainda, que terminaria por negar aquilo que lhes é mais próprio ou especifico, formulado ou designado comumente em expressões como "espiritual”, "religioso", "transcendente" etc.

E tal suspeita ou crítica não seria completamente absurda e descabida. Curiosa e surpreendentemente, entretanto, a abordagem de Boaventura de Sousa Santos extrapola o nível da pura constatação e da instrumentalização, tocando no núcleo mesmo da experiência religiosa, particularmente nas tradições monoteístas. Não apenas constata a participação de muitos crentes e movimentos religiosos nas lutas por justiça e seu potencial contra-hegemônico, mas percebe e mostra como estes crentes e movimentos baseiam esta participação em "crenças religiosas ou espiritualidades cristãs, islâmicas, judaicas, hindus, budistas e indígenas" (12), isto é, em "referências transcendentes e espirituais" (13). Para estes crentes e movimentos, "Deus se revela no sofrimento humano injusto, nas experiências de vida de todas as vítimas de dominação, opressão ou discriminação e nas lutas de resistência que elas promovem. Como consequência, prestar culto a esse Deus significa denunciar este sofrimento e lutar contra ele" (112s); "Deus está envolvido 
na história dos povos oprimidos e nas suas lutas de libertação" (115). De modo que tratar as religiões a partir e em vista da dignidade humana é tratá-las a partir daquilo que constitui o núcleo mesmo da experiência religiosa ou, em todo caso, uma de suas características fundamentais.

Se isso vale de alguma forma para todos os movimentos e tradições religiosas, vale - de modo muito particular - para a tradição judaico-cristã (SIVATTE, 1997; PIXLEY, 2002; SCHWANTES, 2008a; SCHWANTES, 2008b; LOHFINK, 2001; TAMEZ, 1995). A experiência de Deus, nessa perspectiva, está de tal modo vinculada aos pobres e oprimidos e aos seus processos de libertação que se pode afirmar que a problemática do direito dos pobres ou da prática da justiça constitui "o grande tema bíblico" (BOFF, 1997, 72; SCHAWANTES, 2013) ou o "fio que perpassa, articula e costura as muitas páginas da bíblia”(AQUINO JÚNIOR). Não por acaso, Deus é experimentado e nomeado na Escritura como o Deus dos pobres e oprimidos (Ex 3, 7-9; Dt, 10, 18; Jd 9, 11; Sl 145; Pr 22, 22s; Lc 1, 46-55 etc.); não por acaso, o direito dos pobres e oprimidos aparece na Escritura como direito de Deus (Pr 14, 31; 17, 5; etc); não por acaso, a fidelidade a Deus passa pela observância e defesa do direito dos pobres e oprimidos (Dt 10, 19; Jr 22, 3.16; Jó 31, 13-15; Lc 10, 25-37 etc.); não por acaso, as expectativas messiânicas estão ligadas ao direito dos pobres e oprimidos ( $\mathrm{Sl} \mathrm{72;} \mathrm{Is} \mathrm{11,} \mathrm{1-9;} \mathrm{61,} \mathrm{1-} \mathrm{etc.);} \mathrm{e} \mathrm{não} \mathrm{por}$ acaso, o messianismo de Jesus, a Boa Notícia do reinado de Deus, tem a ver fundamentalmente com a justiça aos pobres e oprimidos (Lc 4, 17-21; 5, 31s; 6, 2023; 7, 21-23; Mt 25, 31-46 etc.) (JEREMIAS, 2008, 159-193; SOBRINO, 1996, 105159).

A afirmação e defesa da dignidade humana ou mais concretamente do direito dos pobres e oprimidos constitui, portanto, o núcleo da experiência judaicocristã de Deus. É o que há de mais religioso, sagrado, espiritual, transcendente etc. Jesus resume toda a Lei no amor a Deus e ao próximo (Mt 22,34-40) ou simplesmente no amor ao próximo (Jo 15, 12) que, segundo a Escritura, constitui o critério de amor a Deus (1 Jo 4, 20), a condição e o critério para herdar a vida 
eterna (Lc 10, 25-37) ou para participar do banquete escatológico (cf. Mt 25, 31-46).

João apresenta, de modo extremamente desconcertante e fantástico, a experiência cristã de Deus ou a fé cristã: "Compreendemos o que é o amor porque Jesus deu a sua vida por nós; portanto, nós também devemos dar a vida pelos irmãos” (1 Jo 3,16): “amados, se Deus nos amou a tal ponto, também nós devemos amar-nos uns aos outros" (1 Jo 4, 11). Talvez o mais lógico fosse afirmar que, se Deus nos ama tanto a ponto de dar a vida por nós, também nós deveríamos dar a vida por ele. Mas a conclusão de João é bem outra: também nós devemos amar e dar a vida por nossos irmãos. Pois só amando os irmãos, ama-se a Deus. O amor a Deus é sempre mediado pelo amor aos irmãos; o amor aos irmãos é o que nos torna afins com Deus, o que nos faz participar de sua vida, enfim, o que nos torna seus filhos/as (1 Jo 1-10).

De modo que, na perspectiva cristã, é impossível "amar a Deus" sem "amar ao próximo", que é, antes de tudo, o que está “caído” à beira do caminho. Socorrêlo em suas necessidades, fazer-lhe justiça, agir com compaixão e misericórdia: eis aqui o núcleo da experiência cristã de Deus ou da fé cristã. Com razão, o papa Francisco podia afirmar em sua catequese no dia 10 de agosto de 2014 que "o essencial do evangelho é a misericórdia” e que, por isso, “o cristão necessariamente deve ser misericordioso". Anos atrás, Jon Sobrino já havia escrito uma bela página sobre A Igreja samaritana e o princípio misericórdia (SOBRINO, 1992, 31-45). A mesma problemática pode ser formulada, em sintonia com a tradição profética na qual Jesus está inserido e com menos riscos de manipulação espiritualista, nos termos de Fé e justiça, conforme fizemos em outra ocasião (AQUINO JÚNIOR).

Importa, em todo caso, insistir na centralidade do sofrimento humano na fé cristã e no modo cristão de lidar e enfrentar-se com o sofrimento humano. Certamente, não há maior dificuldade em reconhecer e aceitar a centralidade do sofrimento humano na fé cristã. O problema começa quando se trata de compreender e enfrentar a complexidade e os níveis de sofrimento; sobretudo, as causas estruturais que promovem sofrimento injusto a grande parte da humanidade. Por um lado, não se pode nem simplificar e banalizar o sofrimento 
humano qualquer que seja (dimensões do sofrimento) nem relativizá-lo a tal ponto que já não se possa falar de urgências, prioridades etc. (níveis de sofrimento). Por outro, não se pode enfrentar eficazmente o sofrimento humano sem enfrentar as causas estruturais que o produzem. Não é simplesmente fruto do acaso nem muito menos da vontade de Deus ou de um suposto destino, mas, em grande medida, é fruto da ação humana individual e social. Enfrentar essas causas significa enfrentar-se e confrontar-se com interesses individuais e coletivos poderosíssimos (conflito).

A percepção e o enfrentamento dessa dimensão estrutural do sofrimento humano são, sem dúvida nenhuma, a marca mais própria e peculiar das teologias da libertação e das igrejas, comunidades ou movimentos a que estas teologias estão vinculadas.

No contexto específico da América Latina, a Conferência de Medellín (1968) já falava de "estruturas opressoras” (Introdução), “estruturas injustas” (Justiça, I), "violência institucionalizada" (Paz, 2, II) e apontava para a necessidade de "novas e renovadas estruturas" (Justiça, II). A conferência de Puebla (1979) chega a falar de “dimensão social do pecado”, de “estruturas de pecado” ou de "pecado social” (28, $70,73,281,452,282,487,1258)$, reflexão que será aprofundada pela teologia da libertação e assumida até pelo magistério da Igreja de Roma. Além da percepção dessa dimensão estrutural da injustiça e de seu caráter pecaminoso, Medellín afirma claramente que "criar uma ordem social justa, sem a qual a paz é ilusória, é uma tarefa eminentemente cristã" (Paz, 2, III) e que "a justiça - consequentemente a paz - conquistam-se por uma ação dinâmica de conscientização e de organização dos setores populares, capaz de urgir os poderes públicos, muitas vezes, impotentes nos seus projetos sociais, sem o apoio popular” (Paz, 2, II).

Estas intuições, que depois serão aprofundadas e solidificadas, estão na base do amplo e complexo processo de engajamento de cristãos, comunidades e grupos cristãos nas mais diversas organizações e lutas populares em todo o continente: caráter estrutural do sofrimento injusto, caráter pecaminoso das estruturas 
injustas, caráter salvífico da transformação das estruturas injustas/pecaminosas da sociedade.

Tudo isso mostra que o "potencial contra-hegemônico" do cristianismo, para além de um fato comprovado pela participação de cristãos e grupos cristãos nas lutas por justiça, constitui sua característica ou sua marca mais fundamental. A tal ponto que se pode dizer que o contrário disso, ou seja, sua instrumentalização pelos grupos e poderes injustos hegemônicos ao longo da história, embora quantitativamente majoritário, constitui uma corrupção ou negação radical da experiência cristã de Deus - instrumentalização ideológica (linguagem sociológica), blasfêmia ou idolatria (linguagem teológica).

De modo que a abordagem de Boaventura de Sousa Santos das religiões em geral e do cristianismo em particular, a partir e em função das lutas sociais contra o sofrimento humano injusto, se não esgota a experiência cristã de Deus nem sequer a prática cristã do amor, toca ou diz respeito ao seu núcleo mais fundamental. Não sem razão, Paulo fala da fé cristã como uma "fé ativada pelo amor" (Gl 5,6), e os evangelhos falam do fazer-se "próximo" dos caídos, socorrendo-os em suas necessidades, como condição e critério para herdar a vida eterna ou para participar do banquete final (Lc 10, 25-37; Mt, 25, 31-46). A experiência eclesial latinoamericana, confirmada pelo papa Francisco, também em sua Exortação Apostólica A alegria do Evangelho, mostra a necessidade de articular bem a prática cotidiana da solidariedade com a transformação das estruturas da sociedade (cf. EG 188s, 202), o que só é possível, como já indicava o Documento de Medellín, mediante "uma ação dinâmica de conscientização e de organização dos setores populares" (Paz, 2, II). Fica claro, então, o vínculo constitutivo e essencial entre cristianismo, amor ao próximo, estruturas da sociedade e lutas populares.

\section{Conclusão}

A forma mais fecunda e mais eficaz de viver o pensar o cristianismo em sociedades plurais como as nossas, é vivê-lo e pensá-lo no contexto mais amplo e 
complexo de afirmação e promoção da dignidade humana; particularmente, por meio das lutas por justiça, isto é, das lutas pelos direitos dos pobres, oprimidos e marginalizados em nossas sociedades. Isso tanto por se tratar de uma necessidade e urgência de nosso tempo (ou de todos os tempos!?) quanto por se tratar de algo que, se não constitui o núcleo mesmo do cristianismo, constitui, em todo caso, uma de suas marcas/características e tarefas fundamentais. Afinal de contas, a experiência cristã de Deus, que é amor, só é possível na prática do amor para com o "próximo" que é, antes de tudo, o "caído à beira do caminho"; amor que tem tanto uma dimensão interpessoal (cuidado e na solidariedade com as pessoas que sofrem), quanto uma dimensão estrutural (lutas pela transformação da sociedade).

Desta forma, o cristianismo, ao mesmo tempo em que encontra um lugar na sociedade atual, encontra sua mediação histórica atual mais adequada; ao mesmo tempo em que contribui com a afirmação e a ampliação justiça social, contribui para a instauração do reinado de Deus, cujo critério e cuja medida são sempre as necessidades e os direitos dos pobres, oprimidos e fracos, n’Ele, juízes e senhores de nossas sociedades e de nossas igrejas (Mt, 25, 31-46).

\section{REFERÊNCIAS}

AQUINO JÚNIOR, Francisco de. Fé e justiça. Disponível:

$<$ http://theologicalatinoamericana.com/?p=183>. Acesso em: 7 mai 2015.

ARAÚJO, Luiz Bernardo Leite. Religião e modernidade em Habermas. São Paulo: Loyola, 1996

BOFF, Leonardo. Os direitos dos pobres como direitos de Deus. In. BOFF, Leonardo. Do lugar do pobre. Petrópolis: Vozes, 1997. p. 63-77.

CUNICO, Geraldo. Jürgen Habermas (1929 - ). A religião além dos limites da razão comunicativa. In: PENZO, Giorgio; GIBELINI, Rosino. Deus na filosofia do século XX. São Paulo: Loyola, 1998. p. 507-519.

GONZÁLEZ, Antonio. Orden mundial y liberación. Estudios Centroamaricanos, El Salvador, n. 549, p. 629-652, 1994. [Publicação online: RELat - Revista Eletrônica 
Latinoamericana de Teología, n. 100. Disponível em:

<http://servicioskoinonia.org/relat/10o.htm\#Inicio>. Acesso em: 7 mai 2015.

GONZÁLEZ, Antonio. Um solo mundo. La relevancia de Zubiri para la teoria social.1995. Tesis (doctoral) - Universidad Centroamericana José Simeón Cañas, San Salvador, 1995. Disponível em:

<http://www.uca.edu.sv/facultad/chn/c1170/agtdind.html>. Acesso em: 23 jul 2015.

[Arquivo em PDF disponível em:

<http://www.uca.edu.sv/filosofia/admin/files/1201404090.pdf >].

HABERMAS, Jürgen; RATZINGER, Joseph. Dialética da secularização. Sobre razão e religião. Aparecida: Ideias \& Letras, 2007.

JEREMIAS, Joachim. Teologia do Novo Testamento. São Paulo: Hagnos, 2008.

LOHFINK, Norbert. Hinos dos pobres. O Magnificat, os Hodayot de Qumran e alguns Salmos tardios. São Paulo: Loyola, 2001.

NOGOSEKE, Elisabet; CASTAMAN, Terezinha. Pistis \& Praxis, Curitiba, v. 6, n. 3 p. 1097-1104, 2014.

OLIVEIRA, Manfredo Araújo de. A presença da religião no novo contexto societário. In: OLIVEIRA, Manfredo Araújo de. A religião na sociedade urbana e pluralista. São Paulo: Paulus. p. 61-108.

PIXLEY, Jorge. A história de Israel a partir dos pobres. Petrópolis: Vozes, 2002.

SANTOS, Boaventura de Sousa. A globalização e as ciências sociais. São Paulo: Cortez, 2001.

SANTOS, Boaventura de Sousa. Se Deus fosse um ativista dos direitos humanos. São Paulo: Cortez, 2014.

SCHWANTES, Milton. Breve história de Israel. São Leopoldo: Oikos, 2008.

SCHWANTES, Milton. História de Israel: Local e origens. São Leopoldo: Oikos, 2008.

SCHWANTES, Milton. O direito dos pobres. São Leopoldo: Oikos - São Bernardo do Campo: Editeo, 2013.

SIVATTE, Rafael. Dios camina con los pobres. Introducción al Antiguo y Nuevo Testamento. San Salvador: UCA, 1997.

SOBRINO, Jon. Jesus, o libertador. A história de Jesus de Nazaré. Petrópolis: Vozes, 1996.

SOBRINO, Jon. La Iglesia samaritana y el principio misericordia. In: SOBRINO, Jon. El principio-misercordia. Bajar de la cruz a los pueblos crucificados. Santander: Sal Terrae, 1992. p. 31-45. 
TAMEZ, Elsa. Contra toda condenação. A justificação pela fé partindo dos excluídos. São Paulo: Paulus, 1995.

TOLDY, Tereza Martinho. Revista Crítica de Ciências Sociais, Coimbra, n. 103, 2014. Disponível em: <http://rccs.revues.org/5586>. Acesso em: 19 jul. 2015. 